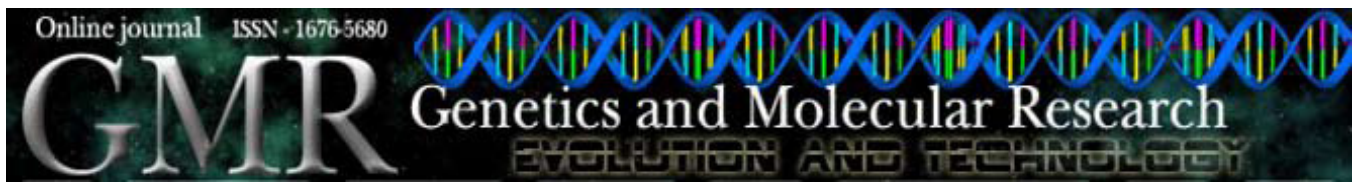

\title{
Changes in gene expression profiles of bovine embryos produced in vitro, by natural ovulation, or hormonal superstimulation
}

\author{
T.C.D. Mundim ${ }^{1}$, A.F. Ramos ${ }^{2}$, R. Sartori ${ }^{4}$, M.A.N. Dode ${ }^{1,2}$, E.O. Melo ${ }^{2}$, \\ L.F.S. Gomes ${ }^{3}$, R. Rumpf ${ }^{1,2}$ and M.M. Franco ${ }^{1,2,3}$ \\ ${ }^{1}$ Universidade de Brasília, Faculdade de Agronomia e Veterinária, Brasília, DF, Brasil \\ ${ }^{2}$ Laboratório de Reprodução Animal, \\ Embrapa Recursos Genéticos e Biotecnologia, Brasília, DF, Brasil \\ ${ }^{3}$ Programa de Pós-Graduação em Ciências Veterinárias, \\ Universidade Federal de Uberlândia, Uberlândia, MG, Brasil \\ ${ }^{4}$ Departamento de Zootecnia, Escola Superior de Agricultura “Luiz de Queiroz", \\ Universidade de São Paulo, Piracicaba, SP, Brasil \\ Corresponding author: M.M. Franco \\ E-mail: mfranco@cenargen.embrapa.br
}

Genet. Mol. Res. 8 (4): 1398-1407 (2009)

Received July 1, 2009

Accepted September 28, 2009

Published November 24, 2009

\begin{abstract}
Embryos produced by hormonal superstimulation have been used as an in vivo control in most published research on embryo gene expression. However, it is not known if this is the most appropriate control for gene expression profile studies. We compared the expression of $G R B-10$, $I G F-I I, I G F-I I R, M n S O D, G P X-4$, catalase, BAX, and interferon- $\tau$ genes, in embryos produced in vivo by hormonal superovulation (SOV), by in vitro fertilization (IVF) or in vivo without any hormonal stimulus (NOV). GRB10 was less expressed in NOV than IVF embryos, whereas no differences were found for the other genes. The genes related to stress response were then grouped and compared; the sum of expression of $M n S O D, G P X-4$, and catalase genes tended to be greater in IVF than NOV embryos. A correlation analysis was performed; we found a distinct behavior for NOV embryos when compared with SOV and IVF in the expression of GRB-10,IGF-II
\end{abstract}


and IGF-IIR genes. However, the behavior of these genes was similar in SOV and IVF embryos. We conclude that ovarian hormonal stimulation can affect embryos by altering gene expression. Although this conclusion was based on investigation of only a few genes, we suggest that SOV embryos should be used with caution as a control in gene expression studies.

Key words: Cattle; Assisted reproduction technologies; Animal reproduction

\section{INTRODUCTION}

The development of several assisted reproduction technologies (ART), such as artificial insemination, superovulation (SOV) and embryo transfer, and in vitro embryo production (in vitro fertilization, IVF), has made contributions to animal breeding programs and to the dissemination of breeds that are at risk of extinction. These technologies allow the more rapid introgression of desirable alleles in livestock populations, increasing genetic improvement in a shorter period of time (Meuwissen, 1998). Furthermore, in the near future, animal cloning and transgenesis may greatly enhance the pharmaceutical industry and xenografts, among many other applications (Melo et al., 2007).

Although substantial progress has been achieved in animal ART in the last decade, the overall efficiency of some of these techniques is still less than expected. For both humans and animals, many factors can affect ART efficiency. In animal embryo tranfer, for instance, the variability in hormonal superstimulation response, nutritional status, and developmental synchrony between the transferred embryo and the recipient female are the most significant factors (Spearow and Barkley, 1999; Spearow et al., 1999; Perez Mayorga et al., 2000; Simoni et al., 2002; de Castro et al., 2003, 2004; Santos et al., 2008). Regarding IVF, in vitro culture of oocytes and embryos, composition of the media, and environmental conditions can have a profound effect on the outcome (Gardner and Lane, 2005). In animal cloning, besides the factors previously mentioned, the capacity of the oocyte cytoplasm to correctly perform nuclear reprogramming is fundamental for cloning success (Smith et al., 2005; Sasaki and Matsui, 2008).

Currently, the parameters used to evaluate IVF efficiency are cleavage rate, blastocyst rate and morphological appearance of the embryos at the time of transfer. Although these parameters give an indication of embryo quality, they do not reflect total embryo normalcy, since the pregnancy rates of these embryos rarely exceed $50 \%$. Thus, there is a need to establish alternative strategies, to more objectively analyze the developmental potential of the IVF embryos. Therefore, the evaluation of molecular parameters has become essential in order to understand the biochemical processes involved in the development of healthy embryos. These parameters will be critical in developing a culture medium that can meet embryo requirements, as well as improve IVF protocols (Niemann and Wrenzycki, 2000).

In the majority of current publications, the embryos produced by hormonal superstimulation are the traditional in vivo control, but such embryos may differ substantially from the naturally produced embryo, and may not be an ideal control for gene expression profile studies. In fact, several studies have reported the influence of ovarian superstimulation on imprinted gene expression in the placenta (Fortier et al., 2008) and on embryo quality (Rossignol et al., 2006; Fauque et al., 2007; Sato et al., 2007). Therefore, for many reasons, the quality and biochemistry of embryos produced by different ARTs may be distinct. 
The objective of this study was to compare the expression profile of some candidate genes involved in embryo development and oxidative stress, among embryos produced in vivo by hormonal superstimulation, by IVF, or in vivo without any hormonal stimulus.

\section{MATERIAL AND METHODS}

\section{Animals}

Forty-one F1 crossbred Simmental x Nellore cyclic heifers, and two Curraleiro bulls were used. The heifers were 2 to 3 years old and the bulls were 7 years old. All animals were kept on pasture (Brachiaria brizantha), with free access to water and mineral supplementation at EMBRAPA, Federal District, Brazil. The animals were handled in accordance with Brazilian law and following Embrapa's procedures for animal care.

\section{Embryo production through natural ovulation}

The heifers were observed for natural (not induced) estrus for $1 \mathrm{~h}$, twice a day, $12 \mathrm{~h}$ apart, and after estrus detection, they were placed in the presence of one of the bulls to be bred. Seven days after estrus detection, embryos were collected by uterine flushing with DPBS, and only embryos classified as grade I or II, according to the IETS classification (Robertson and Nelson, 1998), were selected. After embryo collection, the heifers were treated $i m$ with 0.150 mg cloprostenol (Prolise, ARSA S.L.R., Argentina) to prevent pregnancy in case of embryo recovery failure. Induced estrus was not used for mating. For the next spontaneous estrus, heifers were bred again, for a total of no more than three times per heifer.

\section{Embryo production through superovulation}

The same animals used to produce natural ovulation (NOV) embryos were superstimulated according to the following protocol: D0: placement of an intravaginal implant containing progesterone (DIB, Syntex S.A., Argentina) and im injection of $2.0 \mathrm{mg}$ estradiol benzoate (Ric-Be, Syntex S.A.); D4 to D7: superstimulation with eight im injections of $250 \mathrm{IU}$ FSH (Pluset, Calier, Spain); D6: $0.150 \mathrm{mg}$ cloprostenol im (Prolise); D6.5: removal of the implant; D8.5 and D9: artificial insemination; D15: embryo collection using the technique described by Neto et al. (2005). The heifers were artificially inseminated with frozen/thawed semen from the same bulls used in the NOV approach. The collection and selection of the embryos were processed as previously described, and the heifers that went through the SOV were not used again for NOV or IVF, due to the possible residual effect of FSH.

\section{Embryo production through in vitro fertilization}

All follicles greater than $5 \mathrm{~mm}$ were removed by transvaginal aspiration (ovum pickup), in order to synchronize the follicular wave emergence. Four days after the ovum pick-up, all follicles greater than $3 \mathrm{~mm}$ were aspirated for recovery of the cumulus-oocyte complexes. The cumulus-oocyte complexes showing homogenous cytoplasm and with at least three layers of cumulus cells were selected, matured, fertilized, and cultured in vitro. 
In vitro embryos were produced as described by Pereira et al. (2005). Briefly, following selection, oocytes were matured in TCM-199 (Invitrogen, CA, USA) supplemented with $\mathrm{LH}, \mathrm{FSH}$, antibiotics and $10 \% \mathrm{FBS}$ (Invitrogen) for $22 \mathrm{~h}$ at $39^{\circ} \mathrm{C}$ in $5 \% \mathrm{CO}_{2}$ in air. Matured oocytes were inseminated with frozen/thawed semen, from the same bulls used in the other experimental groups, using a final concentration of $1 \times 10^{6}$ spermatozoa $/ \mathrm{mL}$. After $18 \mathrm{~h}$ of coincubation, presumptive zygotes were washed and transferred to SOFaaci medium (Holm et al., 1999), supplemented with $2.77 \mathrm{mM}$ myo-inositol and 5\% FBS. Embryos were cultured for 7 days and only grade I and II embryos were used.

The selected embryos from all treatments (NOV, SOV and IVF) were immersed in Trizol Reagent (Invitrogen) and frozen at $-80^{\circ} \mathrm{C}$, for later RNA extraction and gene expression evaluation. Embryo production was performed in all treatments until three pools of 15 embryos (6 morulae and 9 blastocysts) from each treatment were formed.

\section{RNA extraction}

From three pools (15 embryos/pool), total RNA was isolated with Trizol Reagent (Invitrogen) for each treatment: NOV, SOV and IVF, according to manufacturer instructions, with minor modifications. Briefly, the tubes containing the embryos and $100 \mu \mathrm{L}$ Trizol (Invitrogen) were mixed, before standing for $5 \mathrm{~min}$ at room temperature. Glycogen ( $25 \mu \mathrm{g}$; Invitrogen) and chloroform ( $20 \mu \mathrm{L}$; Merck) were added. The samples were vigorously shaken and incubated at room temperature for $2 \mathrm{~min}$, and centrifuged at $13,680 \mathrm{~g}$ for $15 \mathrm{~min}$ at $4^{\circ} \mathrm{C}$. The upper aqueous phase was removed, and then $50 \mu \mathrm{L}$ cold isopropanol (Mallinckrodt) was added. RNA was precipitated overnight at $-20^{\circ} \mathrm{C}$, followed by centrifugation at $16,060 \mathrm{~g}$, for $7 \mathrm{~min}$ at $4^{\circ} \mathrm{C}$. RNA pellets were washed with $100 \mu \mathrm{L} 75 \%$ ethanol (Mallinckrodt), air-dried, and redissolved in $8 \mu \mathrm{L}$ sterile water. Genomic DNA contamination was removed by treatment with 1 unit free DNase-RNase (Promega) for $30 \mathrm{~min}$ at $37^{\circ} \mathrm{C}$. DNase was inactivated by heat for $10 \mathrm{~min}$ at $65^{\circ} \mathrm{C}$. The RNA was used immediately for reverse transcription.

\section{Reverse transcription}

Total RNA from each pool was converted to cDNA using $0.5 \mu \mathrm{g}$ oligo (dT) 20 primers (Invitrogen), $200 \mu \mathrm{M}$ of each dNTP (Invitrogen), 1X RT buffer, $2 \mu \mathrm{L}$ 0.1 M DTT, 40 IU RNase inhibitor (Invitrogen), and $200 \mathrm{IU}$ SuperScript III (Invitrogen) in a final volume of $20 \mu \mathrm{L}$. The RT reaction was performed at $42^{\circ} \mathrm{C}$ for $52 \mathrm{~min}$. The reactions were heat-inactivated at $70^{\circ} \mathrm{C}$ for $15 \mathrm{~min}$. The cDNAs were stored at $-20^{\circ} \mathrm{C}$ until use.

\section{Semi-quantitative polymerase chain reaction}

Polymerase chain reaction (PCR) was performed in $20 \mu \mathrm{L}$, containing 1-2 $\mu \mathrm{L}$ cDNA samples (equivalent to $0.75-1.5$ embryos), 2 IU Platinum Taq DNA polymerase (Invitrogen), $0.5 \mu \mathrm{M}$ of each specific primer, $200 \mu \mathrm{M}$ of each dNTP, $2.0 \mathrm{mM} \mathrm{MgCl}_{2}$, and $1 \mathrm{X}$ PCR buffer. The genes, primer sequences and the amplicon sizes are presented in Table 1. The PCR program used an initial step of $93^{\circ} \mathrm{C}$ for 5 min followed by 29 cycles (GPX, MnSOD, and interferon- $\tau$ ), 32 cycles $(\beta$-actin), 31 cycles $(G A P D H), 33$ cycles (catalase), 35 cycles $(G R B-10)$, or 40 cycles $(B A X, I G F-I I, I G F-I I R)$ at $93^{\circ} \mathrm{C}$ for $40 \mathrm{~s}, 54^{\circ} \mathrm{C}$ for $40 \mathrm{~s}$, and $72^{\circ} \mathrm{C}$ for $1 \mathrm{~min}$. The final 
incubation was done at $72^{\circ} \mathrm{C}$ for $5 \mathrm{~min}$. The exponential phase of the PCR amplification was determined testing 20-40 cycles for each gene (data not shown). As a negative control, reactions were performed using total RNA in PCR or omitting reverse transcriptase during RT. After amplification, the amplicons were electrophoresed on $1.5 \%$ agarose gel, stained with $10 \mathrm{mg} / \mathrm{mL}$ ethidium bromide, and photographed under UV illumination. Gene expression was quantified by densitometry using the ImageJ Software (National Institute of Health), and the relative quantity of mRNA of each gene was determined by the ratio to the constitutive genes.

Table 1. Primer sequences and sizes of amplicons for each specific gene used in the gene expression evaluation.

\begin{tabular}{|c|c|c|}
\hline Gene & Sequence & Amplicon size (bp) \\
\hline \multicolumn{3}{|l|}{$I G F-I I$} \\
\hline Sense & 5'-TCGTGCTGCTATGCTGCTTACC-3' & \multirow[t]{2}{*}{$306 \mathrm{bp}$} \\
\hline Antisense & 5'-ACTGCTTCCAGGTGTCAGATTGG-3' & \\
\hline \multicolumn{3}{|l|}{ IGF-IIR } \\
\hline Sense & 5'-CGCCTACAGCGAGAAGGGGGTTAGTC-3' & \multirow[t]{2}{*}{293 bp } \\
\hline Antisense & 5'-AGAAAAGCGTGCACGTGCGCTTGTC-3' & \\
\hline \multicolumn{3}{|l|}{ GRB-10 } \\
\hline Sense & 5'-GAAGATGGGACAAGCAAAGT-3' & \multirow[t]{2}{*}{$290 \mathrm{bp}$} \\
\hline Antisense & 5'-CTGGCACCAAGTAACCATCTG-3' & \\
\hline \multicolumn{3}{|c|}{ ( } \\
\hline Sense & 5'-CGCCGAGTGTGGTTTAC-3' & \multirow[t]{2}{*}{315 bp } \\
\hline Antisense & 5'-AGGTCCTTCTCTATCACCAG-3' & \\
\hline \multicolumn{3}{|l|}{$\mathrm{MnSOD}$} \\
\hline Sense & 5'-CCCATGAAGCCTTTCTAATCCTG-3' & \multirow[t]{2}{*}{$307 \mathrm{bp}$} \\
\hline Antisense & 5'-TTCAGAGGCGCTACTATTTCCTCC-3' & \\
\hline \multicolumn{3}{|l|}{ Catalase } \\
\hline Sense & 5'-GTTCGCTTCTCCACTGTT-3' & \multirow[t]{2}{*}{454 bp } \\
\hline Antisense & 5'-GGCCATAGTCAGGATCTT-3' & \\
\hline \multicolumn{3}{|c|}{ 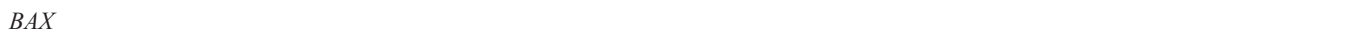 } \\
\hline Sense & 5'-TGCAGAGGATGATCGCAGCTGTG-3' & \multirow[t]{2}{*}{198 bp } \\
\hline Antisense & 5'-CCAATGTCCAGCCCATCATGGTC-3' & \\
\hline \multicolumn{3}{|l|}{ Interferon- $\tau$} \\
\hline Sense & 5'-GCCCTGGTGCTGGTCAGCTA-3' & \multirow[t]{2}{*}{$564 \mathrm{bp}$} \\
\hline Antisense & 5'-CATCTTAGTCAGCGAGAGTC-3' & \\
\hline \multicolumn{3}{|l|}{$\beta$-actin } \\
\hline Sense & 5'-TATTGCTGCGCTCGTGGT-3' & \multirow[t]{2}{*}{$344 \mathrm{bp}$} \\
\hline Antisense & 5'-TCTTCTCACGGTTGGCCT-3' & \\
\hline \multicolumn{3}{|l|}{ GAPDH } \\
\hline Sense & 5'-CCCATCACCATCTTCCAGG-3' & \multirow[t]{2}{*}{$471 \mathrm{bp}$} \\
\hline Antisense & 5'-AGTGAGCTTCCCGTTCAGC-3' & \\
\hline
\end{tabular}

\section{Statistical analysis}

The gene expression data were examined by the $t$-test for parametric data or the MannWhitney test for non-parametric data using the Prophet Software (BBN Systems and Technologies). Comparisons were made among the three different experimental treatments (NOV, SOV and IVF). Initially, quantitative expression of each gene was individually analyzed. Afterward, the sum of the expression of the genes related to stress response (MnSOD, GPX-4, catalase) was used to compare the experimental treatments. The results are reported as means \pm SEM. Finally, to determine the behavior profile of the genes related to embryo development (GRB-10, IGF-II, $I G F-I I R)$, a correlation analysis was performed using the Microsoft Excel 2003 software. 


\section{RESULTS}

In this study, genes related to embryo development (GRB-10, IGF-II, IGF-IIR), stress response ( $M n S O D, G P X-4$, catalase), and embryo quality (BAX, interferon- $\tau$ ) were analyzed in embryos produced by different ARTs. $\beta$-actin and GAPDH average expression was used as constitutive control for all normalizations of the relative gene expression profiles. When the individual gene expression was analyzed, only the GRB-10 demonstrated any difference between the treatments, with less expression in the NOV than SOV $(\mathrm{P}=$ $0.04)$ and IVF $(\mathrm{P}=0.01)$ embryos (Figure 1$)$.

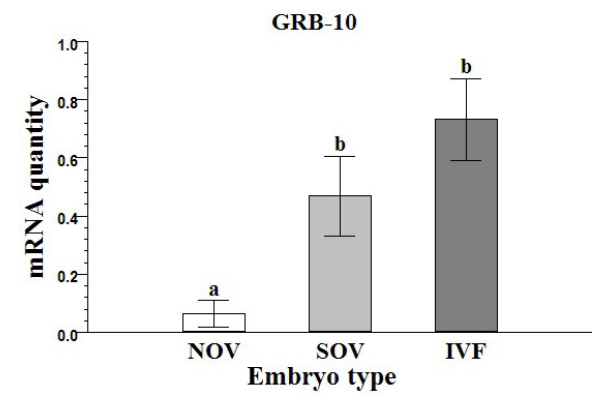

Figure 1. Relative quantity (means \pm SEM) of GRB-10 transcript in embryos produced by natural ovulation (NOV), superovulation (SOV), and in vitro fertilization (IVF). Each treatment group contained three pools of 15 embryos. Different letters indicate difference between groups $(\mathrm{P}<0.05)$.

Besides the individual gene expression analysis, the behavior profile of $I G F-I I, I G F$ $I I R$ and $G R B-10$ was analyzed together, as they utilize the same biochemical pathway (IGF pathway). The profile analysis showed a distinct behavior of the NOV embryos when compared with SOV or IVF embryos; there was a positive correlation between the expression profiles of these three genes in the SOV and IVF embryos $(\mathrm{r}=0.9890 ; \mathrm{P}<0.05)$, but a negative correlation between NOV embryos and the SOV $(r=-0.9429 ; \mathrm{P}<0.05)$ or IVF $(r=-0.8833$; $\mathrm{P}<0.05$ ) treatment (Figure 2).
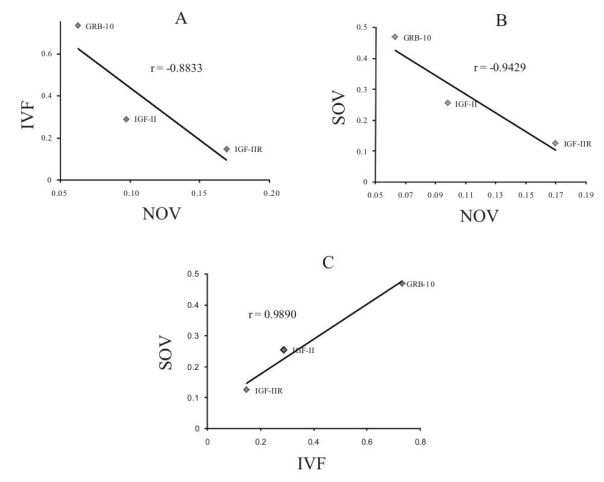

Figure 2. Correlation analysis of the expression of GRB-10,IGF-II, and IGF-IIR genes between embryos produced by natural ovulation (NOV), superovulation (SOV), and in vitro fertilization (IVF). A. NOV vs IVF. B. NOV vs SOV. C. IVF vs SOV. 
Since genes related to stress response have a synergistic effect in protecting cells against toxic oxygen radicals (Corrêa et al., 2008), the relative quantities of $M n S O D, G P X-4$ and catalase genes were analyzed together as a group. The sum was then compared between the treatment groups, and the total expression of stress response tended $(\mathrm{P}=0.10)$ to be greater in IVF than NOV embryos (Figure 3).

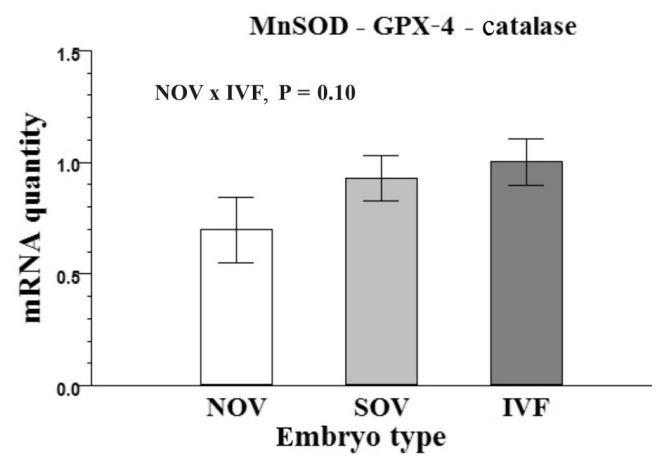

Figure 3. Sum of relative mRNA quantity (means $\pm \mathrm{SEM}$ ) of $M n S O D, G P X-4$, and catalase genes for each source of embryo: natural ovulation (NOV), superovulation (SOV), and in vitro fertilization (IVF). $\mathrm{N}=9$.

\section{DISCUSSION}

The two main parameters used to evaluate the efficiency of embryo production systems are the blastocyst rate and morphological appearance of the embryos ("morphological phenotypes"). Although very useful, these parameters are insufficient for a precise estimate of embryo viability, and therefore the development of alternative methods is needed. Studies of gene expression in cells and embryos provide a better understanding of several biochemical pathways at the molecular level ("molecular phenotype"), and can contribute to the development of more efficient protocols for in vitro embryo production.

Currently, studies of gene expression during embryo development use embryos produced with SOV protocols as an in vivo control (Lequarré et al., 2001; Bertolini et al., 2002; Hall et al., 2005; Sawai et al., 2005; Lonergan et al., 2007; Moore et al., 2007; Nowak-Imialek et al., 2008). However, studies in mice and humans have shown a decrease in the quality of embryos produced after ovarian hormonal stimulation (Rossignol et al., 2006; Fauque et al., 2007; Sato et al., 2007), suggesting that hormonal treatment may affect embryo development and gene expression in many different ways.

We quantified the relative expression of the following genes: IGF-II, IGF-IIR and $G R B-10$, involved in embryo development and placentation (Moore et al., 2007); $B A X$ and interferon- $\tau$, involved in apoptosis and maternal recognition of pregnancy (Corrêa et al., 2008), and $M n S O D$, catalase and GPX-4, related to oxidative stress response (Corrêa et al., 2008). Semi-quantitative RT-PCR was used for this analysis (Lequarré et al., 2001; Nowak-Imialek et al., 2008; Racedo et al., 2008), with $\beta$-actin and GAPDH as reference genes.

Initially, the individual expression of the candidate genes was evaluated in each experimental group (NOV, SOV, and IVF embryos). Among the genes analyzed, only GRB-10 was different, 
which showed a reduced expression in the NOV group (Figure 1). GRB-10 codes for a member of a super-family of protein adapters that bind to mitogenic tyrosine kinase receptors, such as insulin and $I G F-I$ receptors (Lim et al., 2004; Dufresne and Smith, 2005), and can be considered a negative regulator of cellular growth and metabolism. It has been shown in mice that $G R B-10$ has a maternal expression in all tissues, except the brain (Wang et al., 2007), whereas its expression pattern in cattle has not being clearly determined. Overgrowth was observed in GRB-10 knockout mice (Charalambous et al., 2003; Wang et al., 2007), and its imprinting was correlated with some congenital diseases (Charalambous et al., 2003; Lim et al., 2004). Imprinted genes, including GRB-10, were analyzed in humans and mice, and the majority of them had their mRNA expressed during the preimplantation period of development, suggesting their potential role during early development (Ruddock et al., 2004). DNA methylation is the best known epigenetic marker, and is directly involved in the regulation of several imprinted genes that control many routes during early embryo development and placentation (Yamasaki-Ishizaki et al., 2007; Fortier et al., 2008). Several studies have shown the influence of SOV and in vitro manipulations over DNA methylation changes, as well as histone methylation and phosphorylation, during embryo development (Yamasaki-Ishizaki et al., 2007; Fortier et al., 2008). Any negative effect over the epigenetic markers that control the imprinted genes can deregulate their expression, affecting many cell functions. This detrimental effect is well documented in studies with cloned embryos, where the correct reprogramming of the donor cell is essential for normal embryo development (Han et al., 2003; Sawai et al., 2005). In considering this information, we can hypothesize that the higher expression of GRB-10 in SOV and IVF embryos may be due to changes in epigenetic markers that control its expression. Our data are corroborated with observations reported by Pantoja and collaborators (2005) that, under cellular stress, the expression of GRB-10 changed in embryonic mice fibroblasts. These authors believe that stress conditions during cell proliferation cause permanent epigenetic alterations.

Besides individual gene expression analysis, the expression of genes grouped by their functional characteristics was also analyzed in this study. In our interpretation, the behavior of biochemical pathways is more relevant than individual gene expression during embryonic development. We observed similar behaviors among IGF-II, IGF-IIR, and GRB-10 expression for the SOV and IVF embryos (positive correlation), which was different from the behavior observed for NOV embryos (negative correlation) (Figure 2).

When the genes associated with oxidative stress (MnSOD, GPX-4 and catalase) were analyzed individually, no difference in their expression was observed between the different treatments. Our results are contrary to those of other studies, which have shown the expression of genes related to oxidative-defense changes, when utilizing different embryo culture systems (Corrêa et al., 2008) or with different embryonic developmental stages (Lequarré et al., 2001). However, when the sum of relative mRNA quantity was analyzed together, the IVF embryos showed a tendency $(\mathrm{P}=0.10)$ to have a greater expression of these three genes, compared to NOV embryos (Figure 3). It is reported that in vitro culture produces a favorable environment for the production of free radicals (Corrêa et al., 2008) and this could provoke an embryo response, increasing the expression of anti-oxidative genes.

Regarding $B A X$ and interferon- $\tau$ genes, no difference was detected in their expression, neither when their behavior was analyzed together nor individually. These results are in contrast with data from other studies that reported differences in their expression between SOV and IVF embryos (Yang and Rajamahendran, 2002; Rizos et al., 2003). However, it is important to point out that the use of $B A X$ to predict quality and apoptosis in embryos is controversial, with 
contrasting reported results (Vandaele et al., 2008). The contrasting results among studies may be explained by the different sources of embryos produced and different systems utilized.

This study shows, for the first time in cattle, the discrepancies of gene expression between embryos produced after NOV, without any hormonal manipulation, and embryos produced by SOV or IVF. In mice and humans, several undesirable effects of ART have been reported, suggesting that hormonal superstimulation can lead to the production of oocytes with incorrect imprinting and highlighting the need for more research (Sato et al., 2007).

\section{CONCLUSIONS}

We conclude that embryos produced by SOV are different from those produced by natural ovulation. When SOV embryos are used as controls in gene expression profile experiments, the data should be analyzed with caution. The results reported here can be a useful source of information for studies with ART in humans and livestock, demonstrating the concerns regarding possible collateral effects of hormonal treatments or in vitro manipulations of embryos.

\section{ACKNOWLEDGMENTS}

We thank CNPq (Brazil's National Council for Research) for T.C.D. Mundim scholarship and Embrapa for research funding.

\section{REFERENCES}

Bertolini M, Beam SW, Shim H, Bertolini LR, et al. (2002). Growth, development, and gene expression by in vivo- and in vitro-produced day 7 and 16 bovine embryos. Mol. Reprod. Dev. 63: 318-328.

Charalambous M, Smith FM, Bennett WR, Crew TE, et al. (2003). Disruption of the imprinted Grb10 gene leads to disproportionate overgrowth by an Igf2-independent mechanism. Proc. Natl. Acad. Sci. U. S. A. 100: 8292-8297.

Corrêa GA, Rumpf R, Mundim TC, Franco MM, et al. (2008). Oxygen tension during in vitro culture of bovine embryos: effect in production and expression of genes related to oxidative stress. Anim. Reprod. Sci. 104: 132-142.

De Castro F, Ruiz R, Montoro L, Perez-Hernandez D, et al. (2003). Role of follicle-stimulating hormone receptor Ser680Asn polymorphism in the efficacy of follicle-stimulating hormone. Fertil. Steril. 80: 571-576.

De Castro F, Moron FJ, Montoro L, Galan JJ, et al. (2004). Human controlled ovarian hyperstimulation outcome is a polygenic trait. Pharmacogenetics 14: 285-293.

Dufresne AM and Smith RJ (2005). The adapter protein GRB10 is an endogenous negative regulator of insulin-like growth factor signaling. Endocrinology 146: 4399-4409.

Fauque P, Jouannet P, Lesaffre C, Ripoche MA, et al. (2007). Assisted reproductive technology affects developmental kinetics, H19 imprinting control region methylation and H19 gene expression in individual mouse embryos. BMC Dev. Biol. 7: 116.

Fortier AL, Lopes FL, Darricarrere N, Martel J, et al. (2008). Superovulation alters the expression of imprinted genes in the midgestation mouse placenta. Hum. Mol. Genet. 17: 1653-1665.

Gardner DK and Lane M (2005). Ex vivo early embryo development and effects on gene expression and imprinting. Reprod. Fertil. Dev. 17: 361-370.

Hall VJ, Ruddock NT and French AJ (2005). Expression profiling of genes crucial for placental and preimplantation development in bovine in vivo, in vitro, and nuclear transfer blastocysts. Mol. Reprod. Dev. 72: 16-24.

Han DW, Song SJ, Uhum SJ, Do JT, et al. (2003). Expression of IGF2 and IGF receptor mRNA in bovine nuclear transferred embryos. Zygote 11: 245-252.

Holm P, Booth PJ, Schmidt MH, Greve T, et al. (1999). High bovine blastocyst development in a static in vitro production system using SOFaa medium supplemented with sodium citrate and myo-inositol with or without serum-proteins. Theriogenology 52: 683-700.

Lequarré AS, Feugang JM, Malhomme O, Donnay I, et al. (2001). Expression of Cu/Zn and Mn superoxide dismutases 
during bovine embryo development: influence of in vitro culture. Mol. Reprod. Dev. 58: 45-53.

Lim MA, Riedel H and Liu F (2004). Grb10: more than a simple adaptor protein. Front Biosci. 9: 387-403.

Lonergan P, Woods A, Fair T, Carter F, et al. (2007). Effect of embryo source and recipient progesterone environment on embryo development in cattle. Reprod. Fertil. Dev. 19: 861-868.

Melo EO, Canavessi AM, Franco MM and Rumpf R (2007). Animal transgenesis: state of the art and applications. J. Appl. Genet. 48: 47-61.

Meuwissen TH (1998). Optimizing pure line breeding strategies utilizing reproductive technologies. J. Dairy Sci. 81 (Suppl 2): 47-54.

Moore K, Kramer JM, Rodriguez-Sallaberry CJ, Yelich JV, et al. (2007). Insulin-like growth factor (IGF) family genes are aberrantly expressed in bovine conceptuses produced in vitro or by nuclear transfer. Theriogenology 68: 717-727.

Neto AS, Sanches BV, Binelli M, Seneda MM, et al. (2005). Improvement in embryo recovery using double uterine flushing. Theriogenology 63: 1249-1255.

Niemann H and Wrenzycki C (2000). Alterations of expression of developmentally important genes in preimplantation bovine embryos by in vitro culture conditions: implications for subsequent development. Theriogenology 53: 21-34.

Nowak-Imialek M, Wrenzycki C, Herrmann D, Lucas-Hahn A, et al. (2008). Messenger RNA expression patterns of histoneassociated genes in bovine preimplantation embryos derived from different origins. Mol. Reprod. Dev. 75: 731-743.

Pantoja C, de Los Rios L, Matheu A, Antequera F, et al. (2005). Inactivation of imprinted genes induced by cellular stress and tumorigenesis. Cancer Res. 65: 26-33.

Pereira DC, Dode MA and Rumpf R (2005). Evaluation of different culture systems on the in vitro production of bovine embryos. Theriogenology 63: 1131-1141.

Perez Mayorga M, Gromoll J, Behre HM, Gassner C, et al. (2000). Ovarian response to follicle-stimulating hormone (FSH) stimulation depends on the FSH receptor genotype. J. Clin. Endocrinol. Metab. 85: 3365-3369.

Racedo SE, Wrenzycki C, Herrmann D, Salamone D, et al. (2008). Effects of follicle size and stages of maturation on mRNA expression in bovine in vitro matured oocytes. Mol. Reprod. Dev. 75: 17-25.

Rizos D, Gutierrez-Adan A, Perez-Garnelo S, de la Fuente J, et al. (2003). Bovine embryo culture in the presence or absence of serum: implications for blastocyst development, cryotolerance, and messenger RNA expression. Biol. Reprod. 68: 236-243.

Robertson I and Nelson RE (1998). Certification of the Embryo. In: Manual of the International Embryo Transfer Society (Springfellow DA and Seidel SM, eds.). 3rd edn. International Embryo Transfer Society (I.E.T.S.), Savoy, 103-134.

Rossignol S, Steunou V, Chalas C, Kerjean A, et al. (2006). The epigenetic imprinting defect of patients with BeckwithWiedemann syndrome born after assisted reproductive technology is not restricted to the $11 \mathrm{p} 15$ region. J. Med. Genet. 43: 902-907.

Ruddock NT, Wilson KJ, Cooney MA, Korfiatis NA, et al. (2004). Analysis of imprinted messenger RNA expression during bovine preimplantation development. Biol. Reprod. 70: 1131-1135.

Santos JE, Cerri RL and Sartori R (2008). Nutritional management of the donor cow. Theriogenology 69: 88-97.

Sasaki H and Matsui Y (2008). Epigenetic events in mammalian germ-cell development: reprogramming and beyond. Nat. Rev. Genet. 9: 129-140.

Sato A, Otsu E, Negishi H, Utsunomiya T, et al. (2007). Aberrant DNA methylation of imprinted loci in superovulated oocytes. Hum. Reprod. 22: 26-35.

Sawai K, Kageyama S, Moriyasu S, Hirayama H, et al. (2005). Analysis of mRNA transcripts for insulin-like growth factor receptors and binding proteins in bovine embryos derived from somatic cell nuclear transfer. Cloning Stem. Cells 7: 189-198.

Simoni M, Nieschlag E and Gromoll J (2002). Isoforms and single nucleotide polymorphisms of the FSH receptor gene: implications for human reproduction. Hum. Reprod. Update 8: 413-421.

Smith SL, Everts RE, Tian XC, Du F, et al. (2005). Global gene expression profiles reveal significant nuclear reprogramming by the blastocyst stage after cloning. Proc. Natl. Acad. Sci. U. S. A. 102: 17582-17587.

Spearow JL and Barkley M (1999). Genetic control of hormone-induced ovulation rate in mice. Biol. Reprod. 61: 851-856.

Spearow JL, Nutson PA, Mailliard WS, Porter M, et al. (1999). Mapping genes that control hormone-induced ovulation rate in mice. Biol. Reprod. 61: 857-872.

Vandaele L, Goossens K, Peelman L and Van Soom A (2008). mRNA expression of Bcl-2, Bax, caspase-3 and -7 cannot be used as a marker for apoptosis in bovine blastocysts. Anim. Reprod. Sci. 106: 168-173.

Wang L, Balas B, Christ-Roberts CY, Kim RY, et al. (2007). Peripheral disruption of the Grb10 gene enhances insulin signaling and sensitivity in vivo. Mol. Cell Biol. 27: 6497-6505.

Yamasaki-Ishizaki Y, Kayashima T, Mapendano CK, Soejima H, et al. (2007). Role of DNA methylation and histone H3 lysine 27 methylation in tissue-specific imprinting of mouse Grb10. Mol. Cell Biol. 27: 732-742.

Yang MY and Rajamahendran R (2002). Expression of Bcl-2 and Bax proteins in relation to quality of bovine oocytes and embryos produced in vitro. Anim. Reprod. Sci. 70: 159-169. 